\title{
Influence of Nitrogen and Potassium Levels on Plant Water Status, Yield and Economics of Little Millet (Panicum sumatrense) Under Rainfed Condition
}

\author{
Shankar Charate*, M.N. Thimmegowda, B.K. Ramachandrappa and \\ Gangadhar Eswar Rao \\ Department of Agronomy, University of Agricultural Sciences, GKVK, \\ Bengaluru-560 065, Karnataka, India \\ *Corresponding author
}

\section{A B S T R A C T}

\begin{tabular}{|l|}
\hline Ke y w or d s \\
Grain yield, Little \\
millet, Relative \\
$\begin{array}{l}\text { Water content, } \\
\text { Economics. }\end{array}$ \\
\hline Article Info \\
\hline $\begin{array}{l}\text { Accepted: } \\
04 \text { October } 2017 \\
\text { Available Online: } \\
\text { 10 December } 2017\end{array}$ \\
\hline
\end{tabular}

A field investigation was conducted during Kharif -2016 at AICRP on Dryland Agriculture, University of Agricultural Sciences, GKVK, Bengaluru, Karnataka to study the influence of nitrogen and potassium levels on plant water status, yield and economics of little millet (Panicum sumatrense) under rainfed condition. The experiment was laid out in Randomized complete block consisting of twelve treatments of different combination of nitrogen (3) and potassium (4) replicated thrice. Significantly higher relative water content (RWC) was maintained with application of $40 \mathrm{~kg} \mathrm{~N}$ and $20 \mathrm{~kg} \mathrm{~K}_{2} \mathrm{O} \mathrm{ha}{ }^{-1}$ (78.3, 73.2 and $46.8 \%$, respectively) at 40, $60 \mathrm{DAS}$ and at harvest as compared to $20 \mathrm{~kg} \mathrm{~N}$ and $0 \mathrm{~kg} \mathrm{~K}_{2} \mathrm{O} \mathrm{ha}{ }^{-1}(63.3,58.9$ and $36.9 \%$, respectively). The maintenance of higher water in plant resulted in higher grain yield $\left(730 \mathrm{~kg} \mathrm{ha}^{-1}\right)$, net income $\left(\square 20107 \mathrm{ha}^{-1}\right)$ and $\mathrm{B}$ : $\mathrm{C}$ ratio (2.30) with $40 \mathrm{~kg} \mathrm{~N}$ and $20 \mathrm{~kg} \mathrm{~K}_{2} \mathrm{O} \mathrm{ha}^{-1}$ as compared to all other treatments.

\section{Introduction}

Recently, there has been increasing recognition of millets in view of quality of food, lower input and cost of production, wider adjustability to climate, soil etc.

Among the millets, little millet is one known by many regional names viz., Kutki, Gundli (Hindi), Suan (Oriya), Saame or Saave (Kannada), Sumai (Tamil) in different parts of the country. Cultivation of little millet is mostly confined to hilly tract and poor tribal communities of the country. It is also cultivated in plains by non-tribals in southern states in India.
Poor soil fertility and erratic rains are the most important constraints to crop production in rain fed ecosystem. Soil fertility management i.e. nutrient management particularly nitrogen and potassium plays a major role in increasing production and productivity of little millet. Nitrogen is an essential nutrient and key limiting factor in crop production. It is considered as one of the most important plant nutrients for growth and development of crop plant. It also plays an important role in synthesis of chlorophyll and amino acids that contribute to photosynthesis for better growth and protein metabolism in 
plants. Potassium is an essential macro nutrient required for proper plant growth. It is involved in large number of physiological processes like osmo-regulation, cation-anion balance, protein synthesis and activation of enzymes. Being a major inorganic solute, it plays a key role in the plant water balance. It also reduces lodging, imparts disease, pest and drought resistance, and improves quality and self-life of the produce (Sharma and Agarwal, 2002).

Efficient and balanced fertilizer management plays an important role in increasing crop yield through efficient utilization of limited moisture /water supply by adjusting the crop growth and tolerance level to drought condition. Therefore, an attempt was made to assess the influence of nitrogen and potassium levels on plant water status and yield in little millet.

\section{Materials and Methods}

A field experiment was conducted during Kharif 2016 at ACIRP on Dryland Agriculture, UAS, GKVK, Bengaluru, Karnataka, India on red sandy loam soil situated in Eastern Dry Zone of Karnataka at a latitude of $12^{\circ} 58^{\prime} \mathrm{N}$ and longitude of $75^{\circ}$ $35^{\prime} \mathrm{E}$ with an altitude of 930 meter above mean sea level. The soil type of experimental site was red sandy loam in texture, which is deep and possesses good drainage with a slightly acidic soil reaction, low in organic $\mathrm{C}$ and available $\mathrm{N}$, high in available $\mathrm{P}_{2} \mathrm{O}_{5}$, medium in available $\mathrm{K}_{2} \mathrm{O}$. The field experiment was laid out in Randomized complete block design in factorial concept consisting of twelve treatment combinations of three $\mathrm{N}$ levels $\left(20,40\right.$ and $\left.60 \mathrm{~kg} \mathrm{~N} \mathrm{ha}^{-1}\right)$ and four $\mathrm{K}$ levels $\left(0,10,20\right.$ and $30 \mathrm{~kg} \mathrm{~K}_{2} \mathrm{O}$ $\left.\mathrm{ha}^{-1}\right)$. The field was prepared by repeated ploughing and harrowing. FYM was applied @ $6.25 \mathrm{t} \mathrm{ha}^{-1}$ to all the treatments 15 days prior to sowing. The little millet (JK-8) was sown at $30 \times 10 \mathrm{~cm}$ spacing with seed rate of $7.5 \mathrm{~kg} \mathrm{ha}^{-1}$ on September $6^{\text {th }}$ with monsoon rain. The full dose of $\mathrm{N}$ and $\mathrm{K}$ was applied as per the treatment, while $\mathrm{P}_{2} \mathrm{O}_{5} @ 20 \mathrm{~kg} \mathrm{ha}^{-1}$ to all the treatments basally through urea, MOP and DAP. All agronomic practices are followed as per as package of practices of UAS Bengaluru. The relative water content (\%) was worked out by Weatherly method at 20, 40, 60 DAS and at harvest as formula given below.

Fresh weight (g) - Dry weight $(\mathrm{g})$

RWC $(\%)=$ $\times 100$

Turgid weight (g) - Dry weight $(\mathrm{g})$

Free proline content in leaves was determined during severe dry spell at 60 DAS using the method of suggested by Bates et al., (1973) and expressed in $\mu \mathrm{mol} \mathrm{g}{ }^{-1}$ of fresh weight of leaves. The experimental data was subjected to analysis by using Fisher's method of "Analysis of Variance " (ANOVA) as outlined by Gomez and Gomez (1984). All the data were analyzed and the results are presented and discussed at a probability level of 0.05 per cent.

\section{Results and Discussion}

\section{Effect of nitrogen and potassium on relative water content $(\%)$}

Relative water content in little millet was influenced significantly with different levels of nitrogen and potassium. There was no significant difference observed in relative water content at 20 DAS with different levels of nitrogen and potassium.

With respect to nitrogen levels, the relative water content was significantly higher with application of nitrogen @ $40 \mathrm{~kg} \mathrm{ha}^{-1}(69.5 \%)$ compared to $20 \mathrm{~kg} \mathrm{~N} \mathrm{ha}^{-1}(62.5 \%)$ at $60 \mathrm{DAS}$ and it was at par with the application of nitrogen@60 kg ha ${ }^{-1}(70.4 \%)$. Similar trend 
was also noticed at 40 DAS and at harvest. With regard to potassium levels, the relative water content was significantly higher with the application of potassium @ $20 \mathrm{~kg} \mathrm{ha}^{-1}$ (70.01\%) compared to $0 \mathrm{~kg} \mathrm{~K}_{2} \mathrm{O} \mathrm{ha}{ }^{-1}(63.1 \%)$ at 60 DAS and it was also at par with the application of potassium @ $30 \mathrm{~kg} \mathrm{ha}^{-1}$ (70.1\%). Similar trend was noticed at 40 DAS and at harvest. In different combination of $\mathrm{N}$ and $\mathrm{K}$ levels, the relative water content was higher with the application of $40 \mathrm{~kg} \mathrm{~N}+20 \mathrm{~kg}$ $\mathrm{K}_{2} \mathrm{O}$ ha $^{-1}(73.2 \%)$ followed by $40 \mathrm{~kg} \mathrm{~N}+30$ $\mathrm{kg} \mathrm{K}_{2} \mathrm{O} \mathrm{ha}^{-1}(72.3 \%), 60 \mathrm{~kg} \mathrm{~N}+20 \mathrm{~kg} \mathrm{~K}_{2} \mathrm{O}$ $\mathrm{ha}^{-1}(72.1 \%), 60 \mathrm{~kg} \mathrm{~N} \mathrm{ha}^{-1}+30 \mathrm{~kg} \mathrm{~K}_{2} \mathrm{O} \mathrm{ha}{ }^{-1}$ $(71.9 \%)$ at 60 DAS. Lower relative water content was recorded with the application of $20 \mathrm{~kg} \mathrm{~N}+0 \mathrm{~kg} \mathrm{~K}_{2} \mathrm{O}$ (58.9\%). Similar trend was also noticed at 40 DAS and at harvest. This was mainly because, the potassium is involved in osmotic adjustment by accumulating free proline in leaves (Table 1). Thus, $\mathrm{K}$ maintains higher relative water content and lower osmotic potential resulting in improved ability of plants to tolerate drought stress. This was confirmative with the findings of Kant and Kafkafi (2002).

Beringer (1978) reported that potassium being directly involved as an osmotic constituent and also regulates the synthesis of osmotically active organic solutes thereby having an impact on turgor potential. Mukherjee (1974) reported that potassium induces the free proline in leaf disc of maize. Udaykumar et al., (1976) have also reported that enhanced free proline levels as a result of potassium treatment. Potassium induced proline has been noticed in Pennisetum (Huber 1984).

\section{Effect of nitrogen and potassium on yield and yield parameters of little millet}

The yield parameters of little millet are varied due to different levels of nitrogen and potassium (Table 2). With respect to different $\mathrm{N}$ levels, significantly higher yield parameters viz., number of productive tillers $\mathrm{m}^{-1}$ length, ear length and grain weight $\mathrm{m}^{-1}$ length was noticed in the application of nitrogen @ $40 \mathrm{~kg}$ $\mathrm{ha}^{-1}(54.2,14.6 \mathrm{~cm}$ and $21.9 \mathrm{~g}$, respectively) at harvest as compared to the application of nitrogen@ $20 \mathrm{~kg} \mathrm{ha}^{-1}(42.9,11.3 \mathrm{~cm}$ and 16.9 $\mathrm{g}$, respectively) and was on par with the application of nitrogen @ 60 kg ha ${ }^{-1}$ (56.7, $15.2 \mathrm{~cm}$ and $22.5 \mathrm{~g}$, respectively).

With respect to different $\mathrm{K}$ levels, significantly higher yield parameters viz., number of productive tillers $\mathrm{m}^{-1}$ length, ear length and grain weight $\mathrm{m}^{-1}$ length was noticed with the application of potassium @ $20 \mathrm{~kg} \mathrm{ha}{ }^{-1}(53.7,14.5 \mathrm{~cm}$ and $21.7 \mathrm{~g}$, respectively) at harvest as compared to the application of potassium @ $0 \mathrm{~kg} \mathrm{ha}^{-1}$ (46.9, $12.7 \mathrm{~cm}$ and $18.8 \mathrm{~g}$, respectively) and was on par with the application of potassium @ $30 \mathrm{~kg}$ $\mathrm{ha}^{-1}(53.5,14.2 \mathrm{~cm}$ and $21.6 \mathrm{~g}$, respectively). In different combination of $\mathrm{N}$ and $\mathrm{K}$ levels, the application of $40 \mathrm{~kg} \mathrm{~N}+20 \mathrm{~kg} \mathrm{~K}_{2} \mathrm{O} \mathrm{ha}{ }^{-1}$ registered the higher yield parameters viz., number of productive tillers $\mathrm{m}^{-1}$ length, ear length and grain weight $\mathrm{m}^{-1}$ length $(59.6,16.1$ $\mathrm{cm}$ and $23.4 \mathrm{~g}$, respectively) followed by 60 $\mathrm{kg} \mathrm{N}+20 \mathrm{~kg} \mathrm{~K}_{2} \mathrm{O} \mathrm{ha}^{-1}(57.9,15.6 \mathrm{~cm}$ and $23.3 \mathrm{~g}$, respectively), $60 \mathrm{~kg} \mathrm{~N}+30 \mathrm{~kg} \mathrm{~K} \mathrm{~K}_{2} \mathrm{O}$ $\mathrm{ha}^{-1}(57.6,15.4 \mathrm{~cm}$ and $23.3 \mathrm{~g}$, respectively), $60 \mathrm{~kg} \mathrm{~N}+10 \mathrm{~kg} \mathrm{~K}_{2} \mathrm{O} \mathrm{ha}{ }^{-1}(56.7,15.3 \mathrm{~cm}$ and $22.2 \mathrm{~g}$, respectively) and $40 \mathrm{~kg} \mathrm{~N}+30 \mathrm{~kg}$ $\mathrm{K}_{2} \mathrm{O} \mathrm{ha}^{-1}(56.5,15.2 \mathrm{~cm}$ and $21.9 \mathrm{~g}$, respectively). Lower yield parameters were registered with the application of $20 \mathrm{~kg} \mathrm{~N}+0$ $\mathrm{kg} \mathrm{K}_{2} \mathrm{O} \mathrm{ha}{ }^{-1}(40.5,10.7 \mathrm{~cm}$ and $14.4 \mathrm{~g}$, respectively).

These higher yield parameters ultimately improve grain and straw yield in little millet (Table 2). Among different nitrogen levels, significantly higher grain and straw yield was observed with the application of nitrogen @ $40 \mathrm{~kg} \mathrm{ha}{ }^{-1}$ (686 and $1243 \mathrm{~kg} \mathrm{ha}{ }^{-1}$, respectively) as compared $20 \mathrm{~kg} \mathrm{~N} \mathrm{ha}^{-1}$ (529 and $1042 \mathrm{~kg} \mathrm{ha}^{-1}$, respectively). 
Table.1 Relative water content (\%) and proline content in little millet as influenced by different levels of nitrogen and potassium

\begin{tabular}{|c|c|c|c|c|c|}
\hline Treatments & 20 DAS & 40 DAS & 60 DAS & At harvest & Proline content \\
\hline \multicolumn{6}{|c|}{ Nitrogen levels $(\mathbf{N})$} \\
\hline $\mathrm{N}_{1}: 20 \mathrm{~kg} \mathrm{ha}^{-1}$ & 61.9 & 67.0 & 62.5 & 39.3 & 49.8 \\
\hline $\mathrm{N}_{2}: 40 \mathrm{~kg} \mathrm{ha}^{-1}$ & 64.7 & 74.6 & 69.5 & 44.2 & 52.3 \\
\hline $\mathrm{N}_{3}: 60 \mathrm{~kg} \mathrm{ha}^{-1}$ & 65.4 & 75.4 & 70.4 & 44.8 & 52.4 \\
\hline S. Em. \pm & 3.3 & 0.6 & 0.5 & 0.4 & 0.2 \\
\hline $\mathrm{CD}(\mathrm{p}=0.05)$ & NS & 1.6 & 1.6 & 1.1 & 0.6 \\
\hline \multicolumn{6}{|c|}{ Potassium levels (K) } \\
\hline $\mathrm{K}_{1}: 0 \mathrm{~kg} \mathrm{ha}^{-1}$ & 60.0 & 67.9 & 63.1 & 39.8 & 50.0 \\
\hline $\mathrm{K}_{2}: 10 \mathrm{~kg} \mathrm{ha}^{-1}$ & 62.8 & 71.2 & 66.7 & 42.2 & 51.0 \\
\hline $\mathrm{K}_{3}: 20 \mathrm{~kg} \mathrm{ha}^{-1}$ & 65.7 & 74.9 & 70.0 & 44.6 & 52.7 \\
\hline $\mathrm{K}_{4}: 30 \mathrm{~kg} \mathrm{ha}^{-1}$ & 67.6 & 75.1 & 70.1 & 44.6 & 52.4 \\
\hline S. Em. \pm & 3.8 & 0.6 & 0.6 & 0.4 & 0.2 \\
\hline $\mathrm{CD}(\mathrm{p}=0.05)$ & NS & 1.9 & 1.8 & 1.3 & 0.7 \\
\hline \multicolumn{6}{|c|}{ Interaction $(\mathbf{N} \times \mathbf{K})$} \\
\hline $\mathrm{N}_{1} \mathrm{~K}_{1}$ & 57.1 & 63.3 & 58.9 & 36.9 & 48.9 \\
\hline $\mathrm{N}_{1} \mathrm{~K}_{2}$ & 61.2 & 64.7 & 60.2 & 37.8 & 49.1 \\
\hline $\mathrm{N}_{1} \mathrm{~K}_{3}$ & 62.2 & 69.1 & 64.7 & 40.9 & 50.5 \\
\hline $\mathrm{N}_{1} \mathrm{~K}_{4}$ & 67.0 & 70.8 & 66.1 & 41.8 & 50.9 \\
\hline $\mathrm{N}_{2} \mathrm{~K}_{1}$ & 61.3 & 67.5 & 62.6 & 39.4 & 49.8 \\
\hline $\mathrm{N}_{2} \mathrm{~K}_{2}$ & 63.5 & 74.8 & 69.9 & 44.5 & 51.8 \\
\hline $\mathrm{N}_{2} \mathrm{~K}_{3}$ & 66.5 & 78.3 & 73.2 & 46.8 & 54.0 \\
\hline $\mathrm{N}_{2} \mathrm{~K}_{4}$ & 67.4 & 77.6 & 72.3 & 46.1 & 53.6 \\
\hline $\mathrm{N}_{3} \mathrm{~K}_{1}$ & 61.5 & 72.9 & 67.7 & 43.0 & 51.2 \\
\hline $\mathrm{N}_{3} \mathrm{~K}_{2}$ & 63.7 & 74.2 & 70.0 & 44.3 & 52.1 \\
\hline $\mathrm{N}_{3} \mathrm{~K}_{3}$ & 68.3 & 77.5 & 72.1 & 46.0 & 53.6 \\
\hline $\mathrm{N}_{3} \mathrm{~K}_{4}$ & 68.3 & 77.0 & 71.9 & 45.9 & 52.7 \\
\hline S. Em. \pm & 6.7 & 1.1 & 1.1 & 0.7 & 0.4 \\
\hline $\mathrm{CD}(\mathrm{p}=0.05)$ & NS & 3.2 & 3.2 & 2.2 & 1.2 \\
\hline
\end{tabular}

CD: Critical difference; NS: Non- significant 
Table.2 Yield and yield parameters of little millet as influenced by different levels of nitrogen and potassium

\begin{tabular}{|c|c|c|c|c|c|c|}
\hline Treatments & $\begin{array}{c}\text { No of } \\
\text { productive } \\
\text { tillers } \mathbf{m}^{-1}\end{array}$ & $\begin{array}{l}\text { Ear length } \\
\quad(\mathrm{cm})\end{array}$ & $\begin{array}{c}\text { Grain } \\
\text { weight } \mathbf{m}^{-1} \\
\text { length }(g)\end{array}$ & $\begin{array}{c}1000 \\
\text { seed } \\
\text { weight } \\
\text { (g) }\end{array}$ & $\begin{array}{c}\text { Grain } \\
\text { yield } \\
\left(\mathbf{k g ~ h a}^{-1}\right)\end{array}$ & $\begin{array}{c}\text { Straw } \\
\text { yield (kg } \\
\left.\text { ha }^{-1}\right)\end{array}$ \\
\hline \multicolumn{7}{|c|}{ Nitrogen levels (N) } \\
\hline $\mathrm{N}_{1}: 20 \mathrm{~kg} \mathrm{ha}^{-1}$ & 42.9 & 11.3 & 16.9 & 2.5 & 529 & 1042 \\
\hline $\mathrm{N}_{2}: 40 \mathrm{~kg} \mathrm{ha}^{-1}$ & 54.2 & 14.6 & 21.9 & 2.5 & 686 & 1243 \\
\hline $\mathrm{N}_{3}: 60 \mathrm{~kg} \mathrm{ha}^{-1}$ & 56.7 & 15.2 & 22.5 & 2.6 & 703 & 1258 \\
\hline S. Em. \pm & 0.9 & 0.3 & 0.4 & 0.1 & 12 & 17 \\
\hline $\mathrm{CD}(\mathrm{p}=0.05)$ & 2.5 & 0.7 & 1.1 & $\mathrm{NS}$ & 34 & 50 \\
\hline \multicolumn{7}{|c|}{ Potassium levels (K) } \\
\hline $\mathrm{K}_{1}: 0 \mathrm{~kg} \mathrm{ha}^{-1}$ & 46.9 & 12.7 & 18.8 & 2.5 & 588 & 1116 \\
\hline $\mathrm{K}_{2}: 10 \mathrm{~kg} \mathrm{ha}^{-1}$ & 50.8 & 13.5 & 19.7 & 2.5 & 615 & 1161 \\
\hline $\mathrm{K}_{3}: 20 \mathrm{~kg} \mathrm{ha}^{-1}$ & 53.7 & 14.5 & 21.7 & 2.6 & 678 & 1221 \\
\hline $\mathrm{K}_{4}: 30 \mathrm{~kg} \mathrm{ha}^{-1}$ & 53.5 & 14.2 & 21.6 & 2.5 & 675 & 1225 \\
\hline S. Em. \pm & 1.0 & 0.3 & 0.4 & 0.1 & 13 & 19 \\
\hline $\mathrm{CD}(\mathrm{p}=0.05)$ & 2.9 & 0.8 & 1.3 & NS & 39 & 58 \\
\hline \multicolumn{7}{|c|}{ Interaction $(\mathbf{N} \times \mathbf{K})$} \\
\hline $\mathrm{N}_{1} \mathrm{~K}_{1}$ & 40.5 & 10.7 & 14.4 & 2.4 & 448 & 910 \\
\hline $\mathrm{N}_{1} \mathrm{~K}_{2}$ & 40.9 & 10.5 & 15.1 & 2.4 & 471 & 981 \\
\hline $\mathrm{N}_{1} \mathrm{~K}_{3}$ & 43.6 & 11.7 & 18.4 & 2.5 & 575 & 1107 \\
\hline $\mathrm{N}_{1} \mathrm{~K}_{4}$ & 46.4 & 12.2 & 19.9 & 2.5 & 621 & 1168 \\
\hline $\mathrm{N}_{2} \mathrm{~K}_{1}$ & 45.8 & 12.4 & 20.9 & 2.5 & 652 & 1212 \\
\hline $\mathrm{N}_{2} \mathrm{~K}_{2}$ & 54.7 & 14.7 & 21.7 & 2.5 & 676 & 1235 \\
\hline $\mathrm{N}_{2} \mathrm{~K}_{3}$ & 59.6 & 16.1 & 23.4 & 2.6 & 730 & 1282 \\
\hline $\mathrm{N}_{2} \mathrm{~K}_{4}$ & 56.5 & 15.2 & 21.9 & 2.6 & 683 & 1244 \\
\hline $\mathrm{N}_{3} \mathrm{~K}_{1}$ & 54.5 & 14.5 & 21.1 & 2.6 & 664 & 1227 \\
\hline $\mathrm{N}_{3} \mathrm{~K}_{2}$ & 56.7 & 15.3 & 22.2 & 2.6 & 692 & 1259 \\
\hline $\mathrm{N}_{3} \mathrm{~K}_{3}$ & 57.9 & 15.6 & 23.3 & 2.6 & 728 & 1275 \\
\hline $\mathrm{N}_{3} \mathrm{~K}_{4}$ & 57.6 & 15.4 & 23.3 & 2.6 & 727 & 1272 \\
\hline S. Em. \pm & 1.7 & 0.5 & 0.8 & 0.1 & 23 & 34 \\
\hline $\mathrm{CD}(\mathrm{p}=0.05)$ & 5.0 & 1.5 & 2.2 & NS & 68 & 100 \\
\hline
\end{tabular}

CD: Critical difference; NS: Non- significant 
Table.3 Economics of little millet as influenced by different levels of nitrogen and potassium

\begin{tabular}{|c|c|c|c|c|}
\hline Treatments & $\begin{array}{c}\text { Cost of cultivation } \\
\left(\text { Rs. ha }{ }^{-1}\right)\end{array}$ & $\begin{array}{c}\text { Gross return } \\
\left(\text { Rs. } \text { ha }^{-1}\right) \\
\end{array}$ & $\begin{array}{c}\text { Net return } \\
\left(\text { Rs. ha }{ }^{-1}\right)\end{array}$ & B:C ratio \\
\hline $\mathrm{N}_{1} \mathrm{~K}_{1}$ & 14705 & 21994 & 7289 & 1.50 \\
\hline $\mathrm{N}_{1} \mathrm{~K}_{2}$ & 14887 & 23141 & 8254 & 1.55 \\
\hline $\mathrm{N}_{1} \mathrm{~K}_{3}$ & 15074 & 28106 & 13032 & 1.86 \\
\hline $\mathrm{N}_{1} \mathrm{~K}_{4}$ & 15255 & 30299 & 15044 & 1.99 \\
\hline $\mathrm{N}_{2} \mathrm{~K}_{1}$ & 14955 & 31781 & 16826 & 2.12 \\
\hline $\mathrm{N}_{2} \mathrm{~K}_{2}$ & 15137 & 32909 & 17404 & 2.14 \\
\hline $\mathrm{N}_{2} \mathrm{~K}_{3}$ & 15324 & 35431 & 20107 & 2.30 \\
\hline $\mathrm{N}_{2} \mathrm{~K}_{4}$ & 15505 & 33242 & 18105 & 2.19 \\
\hline $\mathrm{N}_{3} \mathrm{~K}_{1}$ & 15199 & 32313 & 17114 & 2.13 \\
\hline $\mathrm{N}_{3} \mathrm{~K}_{2}$ & 15381 & 33668 & 18287 & 2.19 \\
\hline $\mathrm{N}_{3} \mathrm{~K}_{3}$ & 15568 & 35324 & 19756 & 2.27 \\
\hline $\mathrm{N}_{3} \mathrm{~K}_{3}$ & 15749 & 35268 & 19519 & 2.24 \\
\hline $\begin{array}{l}\mathrm{N}_{1}: 20 \mathrm{~kg} \mathrm{ha}^{-1} \\
\mathrm{~N}_{2}: 40 \mathrm{~kg} \mathrm{ha}^{-1} \\
\mathrm{~N}_{3}: 40 \mathrm{~kg} \mathrm{ha}^{-1}\end{array}$ & $\begin{array}{l}\mathrm{K}_{1}: 0 \mathrm{~kg} \mathrm{ha}^{-1} \\
\mathrm{~K}_{2}: 10 \mathrm{~kg} \mathrm{ha}^{-1} \\
\mathrm{~K}_{3}: 20 \mathrm{~kg} \mathrm{ha}^{-1} \\
\mathrm{~K}_{4}: 30 \mathrm{~kg} \mathrm{ha}^{-1}\end{array}$ & & & \\
\hline
\end{tabular}

However, it was at par with the application of $30 \mathrm{~kg} \mathrm{~N} \mathrm{ha}{ }^{-1}$ (703 and $1258 \mathrm{~kg} \mathrm{ha}^{-1}$, respectively). Among different potassium levels, significantly higher grain yield was recorded with the application of potassium @ $20 \mathrm{~kg} \mathrm{ha}{ }^{-1}\left(678\right.$ and $1221 \mathrm{~kg} \mathrm{ha}^{-1}$, respectively) as compared to $0 \mathrm{~kg} \mathrm{~K}_{2} \mathrm{O} \mathrm{ha}{ }^{-1}$ (588 and $1116 \mathrm{~kg} \mathrm{ha}^{-1}$, respectively). However, it was at par with the application of $30 \mathrm{~kg} \mathrm{~K} \mathrm{~K}_{2} \mathrm{O} \mathrm{ha}^{-1}$ (675 and $1225 \mathrm{~kg} \mathrm{ha}^{-1}$, respectively).

With different combination of nitrogen and potassium levels, application of nitrogen @ $40 \mathrm{~kg} \mathrm{ha}^{-1}$ and potassium @ $20 \mathrm{~kg} \mathrm{ha}^{-1}$ recorded significantly higher grain and straw yield (730 and $1282 \mathrm{~kg} \mathrm{ha}^{-1}$, respectively) as compared to $20 \mathrm{~kg} \mathrm{~N}+0 \mathrm{~kg} \mathrm{~K}_{2} \mathrm{O}$ ha $^{-1}$ (448 and $910 \mathrm{~kg} \mathrm{ha}^{-1}$, respectively).

But, it was at par with application of $60 \mathrm{~kg} \mathrm{~N}$ $+20 \mathrm{~kg} \mathrm{~K}_{2} \mathrm{O} \mathrm{ha}^{-1}$ (728 and $1275 \mathrm{~kg} \mathrm{ha}^{-1}$, respectively), $60 \mathrm{~kg} \mathrm{~N}+30 \mathrm{~kg} \mathrm{~K}_{2} \mathrm{O} \mathrm{ha}{ }^{-1}(727$ and $1272 \mathrm{~kg} \mathrm{ha}^{-1}$, respectively) and $60 \mathrm{~kg} \mathrm{~N}+$ $10 \mathrm{~kg} \mathrm{~K} \mathrm{O}_{2} \mathrm{ha}^{-1}$ (692 and $1259 \mathrm{~kg} \mathrm{ha}^{-1}$, respectively).
However, 1000 seed weight found nonsignificant result in all the treatments. These improved yield parameters resulted in grain and straw yield (Table 2). These improved yield parameters mainly because of application of potassium overcome the harmful effects of water stress, retaining water in tissue and thus maintaining higher plant growth and regulating transpiration (Ram Rao, 1986). Whereas, application of nitrogen influence the higher growth parameters and improves dry matter accumulation which in turn improves yield parameters (Bhanu Prasad Reddy et al., 2016).

Later, this dry matter translocated to different yield components thereby increases grain yield (Table 2). Similar results are also reported by Krishna Sastry (1985) and Nandawal et al., (1998).

\section{Economics}

Higher gross return, net return and $\mathrm{B}$ : $\mathrm{C}$ ratio was recorded with the application of $40 \mathrm{~kg} \mathrm{~N}$ 
and $20 \mathrm{~kg} \mathrm{~K}_{2} \mathrm{O}$ (Rs. $35431 \mathrm{ha}^{-1}$, Rs. $20107 \mathrm{ha}^{-}$ 1 and 2.30 , respectively) followed by $60 \mathrm{~kg} \mathrm{~N}$ and $20 \mathrm{~kg} \mathrm{~K}_{2} \mathrm{O}$ (Rs. $35324 \mathrm{ha}^{-1}$, Rs. $19756 \mathrm{ha}^{-}$ 1 and 2.27 , respectively), $60 \mathrm{~kg} \mathrm{~N}$ and $30 \mathrm{~kg}$ $\mathrm{K}_{2} \mathrm{O}$ (Rs. $35268 \mathrm{ha}^{-1}$, Rs. $19519 \mathrm{ha}^{-1}$ and 2.24, respectively). Lower gross return, net return and $\mathrm{B}$ : $\mathrm{C}$ ratio was recorded with the application of $20 \mathrm{~kg} \mathrm{~N}$ and $0 \mathrm{~kg} \mathrm{~K} \mathrm{~K}_{2} \mathrm{O}$ (Rs. $21994 \mathrm{ha}^{-1}$, Rs. $7289 \mathrm{ha}^{-1}$ and 1.50, respectively).

The higher gross return, net return and B: C ratio was due to higher grain yield which ultimately reflects higher B: C ratio (Table 3) associating with balanced nutrition. These results are in line with the findings of Bhomte et al., (2016).

Balanced fertilization in little millet with 40 $\mathrm{kg} \mathrm{N}$ and $20 \mathrm{~kg} \mathrm{~K}_{2} \mathrm{O} \mathrm{ha}{ }^{-1}$ is essential for higher yield and better economics under rainfed condition.

\section{References}

Bates, L. S., Waldren, R. P. and Teare, L.D., 1973, Rapid determinations of free proline for water stress studies. Plant Soil, 39: 205-207.

Beringer, H., 1978, Functions of potassium in plant metabolism with particular reference to yield. In: Potassium in soil and crops (Eds: G.S. Sekhon). New Delhi PR-II. pp. 185-202.

Bhanu Prasad Reddy, K.V., Naga Madhuri, Keerthi Venkaiah and Rathima, T., 2016, Effect of nitrogen and potassium on yield and quality of pearl millet. Int. J. Agric. Inno. Res., 4(4): 678-681.

Bhomte, M.V. Apotikar, V.A. and Pachpole, D.S., 2016, Effect of different fertilizer levels on growth and yield of little millet (Panicum sumatrense) genotypes. Contemporary Res. India, 4(3): 43-45.

Gomez, K. A. and Gomez, A., 1984, Statistical procedures for agricultural research. $2^{\text {nd }}$ Edition, John Willey and Sons, Inc. New York, USA. pp: 234-237.

Huber, S. C., 1984, Biochemical basis for effect of $\mathrm{K}$ deficiency on assimilate, export rate and accumulation of soluble sugars in soybean leaves. Plant physiol., 76: 424-430.

Kant, S. and Kafkafi, U., 2002, Potassium and abiotic stresses in plants, In Potassium for Sustainable Crop Production; Ed: Pasricha, N.S., Bansal, S.K., Eds.; Potash Institute of India: Gurgaon, India, pp. 233-251.

Krishna Sastry, K. S., 1985, Influence of potassium on proline accumulation under stress. PR II Res. Rev. Series, 2:39-45.

Mukherjee, I., 1974, Role of protein synthesis in drought resistance. Can J. Bot., 48: 12351241.

Nandawal, A. S., Hooda, A. and Datta, D., 1998, Effect of substrate moisture and potassium on water relation and $\mathrm{C}, \mathrm{N}$ and $\mathrm{K}$ distribution in Vigna radiata. Biologia Plantarum, 41: 149153.

Rama Rao, N., 1986, Potassium requirements for growth and its related processes determined by plant analysis in wheat. Plant Soil, 96:125131.

Sharma, G. L. And Agarwal, R. M., 2002, Potassium induced changes in nitrate reductase activity in Cicer arietinum L. Indian J. Plant Physio., 7(3): 221-226.

Uday Kumar, M., Rama Rao, S., Prasad, T. G. and Krishna Sastry, K. S., 1976, Effect of potassium on protein accumulation in cucumber cotyledons New Phytol., 77: 593598.

\section{How to cite this article:}

Shankar Charate, M.N. Thimmegowda, B.K. Ramachandrappa and Gangadhar Eswar Rao. 2017. Influence of Nitrogen and Potassium Levels on Plant Water Status, Yield and Economics of Little Millet (Panicum sumatrense) Under Rainfed Condition. Int.J.Curr.Microbiol.App.Sci. 6(12): 150-156. doi: https://doi.org/10.20546/ijcmas.2017.612.020 